\title{
Pengaruh Likuiditas, Leverage, dan Profitabilitas Terhadap Agresivitas Pajak (Studi Empiris Pada Perusahaan Pertambangan Yang Terdaftar Di Bursa Efek Indonesia Periode 2014-2018)
}

\author{
Nely Lestari ${ }^{1}$, Yasir Arafat ${ }^{2}$, Reva Maria Valianti ${ }^{3}$ \\ ${ }^{1}$ Fakultas Ekonomi dan Bisnis Universitas PGRI Palembang, nelylestari167@gmail.com \\ 2Fakultas Ekonomi dan Bisnis Universitas PGRI Palembang, yasir arafat14@yahoo.com \\ ${ }^{3}$ Fakultas Ekonomi dan Bisnis Universitas PGRI Palembang, revavalianti@gmail.co.id
}

\begin{abstract}
Research aims to determine the impact of liquidity, leverage, and profitability on tax aggressiveness. The object in this research is a mining company listed on the Indonesia Stock Exchange period 20142018. This type of research is quantitative. The population of this research is a mining company listed on the Indonesia Stock Exchange period 2014-2018 consisting of 47 mining companies. Research samples consist of 11 companies. Sampling techniques with purposive sampling techniques. The data used is the secondary data of annual reports of mining companies listed on the Indonesia Stock Exchange. Hypothesis testing in this study uses multiple linear regression analysis methods with SPSS program. The results of this research show that liquidity and leverage have no effect on tax aggressiveness. Profitability has significant effect on tax aggressiveness. The value of coefficient of determination or influence of independent variables in this study of the tax aggressiveness amounted to $26.1 \%$. The remainder is $73.9 \%$ capable of being predicted by other variables not examined in this study.
\end{abstract}

Keywords : liquidity, Leverage, profitability of tax aggressiveness

\begin{abstract}
ABSTRAK
Penelitian ini bertujuan untuk mengetahui pengaruh likuiditas, leverage, dan profitabilitas terhadap agresivitas pajak. Objek dalam penelitian ini adalah perusahaan pertambangan yang terdaftar di Bursa Efek Indonesia periode 2014-2018.Jenispenelitian ini adalah kuantitatif. Populasi penelitian ini adalah perusahaanpertambangan yang terdaftar di Bursa Efek Indonesia periode 2014-2018 terdiri dari 47 perusahaan pertambangan. Sampel penelitian terdiri dari 11 perusahaan. Teknik pengambilan sampel dengan teknik purposive sampling. Data yang digunakan berupa data sekunder laporan tahunan perusahaan pertambangan yang terdaftar di Bursa Efek Indonesia. Pengujian hipotesis dalam penelitian ini menggunakan metode analisis regresi linier berganda dengan program SPSS.Hasil penelitian ini menunjukan bahwa likuiditas dan leverage tidak berpengaruh terhadap agresivitas pajak. Profitabilitas berpengaruh signifikan terhadap agresivitas pajak. Nilai koefisien determinasi atau pengaruh variabel independen dalam penelitian ini terhadap agresivitas pajak sebesar $26,1 \%$. Sisanya yaitu sebesar $73,9 \%$ mampu diprediksi oleh variabel lain yang tidak diteliti dalam penelitian ini.
\end{abstract}

Kata Kunci: Likuiditas, Leverage, Profitabilitas Agresivitas Pajak

\section{A. PENDAHULUAN}

Dengan adanya pengusaha yang mendirikan perusahaan di Indonesia, tentu saja hal tersebut dapat menambah serta meningkatkan revenue atau pendapatan negara terutama dari sektor pajak. Disisi lain pemerintah Indonesia juga melaksanakan pembangunan nasional yang berlangsung secara terus menerus dan berkesinambungan dengan tujuan untuk meningkatkan kesejahteraan rakyat. Untuk dapat merealisasikan tujuan tersebut, maka diperlukanlah kontribusi orang pribadi maupun badan kepada negara, berupa pembayaran pajak.Definisi pajak menurut UU 
No. 16 tahun 2009 tentang Ketentuan Umum dan Tata Cara Perpajakan menyatakan bahwa:Kontribusi wajib pajak kepada Negara yang terutang oleh orang pribadi atau badan yang bersifat memaksa berdasarkan Undang-Undang, dengan tidak mendapatkan imbalan secara langsung dan digunakan untuk keperluan Negara sebesar-besarnya untuk kemakmuran rakyat disebut pajak.

Berdasarkan isi Undang-Undang terlihat jelas bahwa pajak merupakan sumber pendapatan bagi negara. Dengan ini pemerintah melakukan upaya untuk meningkatkan kepatuhan wajib pajak dalam membayar pajak guna meningkatkan kesejahteraan rakyat. Akan tetapi pada kenyataannya kesadaran wajib pajak masih sangat rendah hal ini dibuktikan dengan masih banyaknya kasus pengelakan pajak. Seperti yang dilansir oleh suara.com. Sekjen Forum Indonesia Untuk Transparansi Anggaran, Yenny Sucipto, mengungkapkan bahwa " pengelakan pajak merupakan masalah serius di Indonesia. Diduga setiap tahun ada Rp110 triliun yang merupakan angka penghindaran pajak. Kebanyakan adalah badan usaha, sekitar 80 persen, sisanya adalah wajib pajak perorangan." la juga menambahkan bahwa " Kebanyakan memang badan usaha yang bergerak dibidang sektor mineral dan batu bara. Kebanyakan juga adalah perusahaan asing. Ada juga perusahaan berbadan hukum Indonesia, tetapi kepemilikannya sebetulnya oleh asing."

Bagi perusahaan, pajak merupakan faktor yang akan mengurangi keuntungan bagi perusahaan. Hal ini menyebabkan banyak perusahaan melakukan salah satu upaya dengan meminimalkan beban pajak dalam batas di mana aturan yang ada tidak dilanggar karena besar pajak yang dibayarkan tergantung pada besarnya penghasilan, ketika penghasilan semakin besar maka akan semakin besar pajak yang harus dibayarkan. Semakin besar penghematan pajak dilakukan oleh perusahaan tersebut, maka perusahaan tersebut dianggap semakin agresif terhadap pajak. Agresivitas pajak adalah perilaku dalam kecenderungan melakukan manajemen laba, baik dilakukannya secara legal maupun illegal.

Menurut data dari Badan Pusat Statistik "selama 2014-2018 industri pertambangan dan batu bara rata-rata menyumbang $2,3 \%$ terhadap produk domestik bruto (PDB) per tahunnya atau ekuivalen dengan Rp. 235 triliun". Selain itu, batu bara merupakan penyumbang nomor dua dari sektor ekstraktif setelah kelompok minyak, gas, dan panas bumi. Akan tetapi dibalik fantastisnya nilai ekonomi yang dihasilkan industri pertambangan batu bara, ternyata kontribusi pajaknya sangat minim. Dari data Kementrian Keuangan menunjukan tax ratio yang di kontribusikan dari sektor pertambangan mineral dan batu bara (minerba) pada 2016 hanya sebesar 3,9\%, sementara tax ratio nasional pada 2016 sebesar 10,4\%. Rendahnya tax ratio tersebut tidak bisa dilepaskan dari permasalahan penghindaran pajak oleh pelaku industri batu bara. Fenomena penghindaran pajak diduga terjadi pada korporasi besar yang bergerak di sektor tambang batu bara.

\section{B. KAJIAN TEORI \\ 1) Pengertian pajak}

Definisi pajak menurut UU No. 16 tahun 2009 tentang Ketentuan Umum dan Tata Cara Perpajakan menyatakan bahwa: Kontribusi wajib pajak kepada Negara yang terutang oleh orang pribadi atau badan yang bersifat memaksa berdasarkan Undang-Undang, dengan tidak mendapatkan imbalan secara langsung dan digunakan untuk keperluan Negara bagi sebesar-besarnya kemakmuran rakyat disebut dengan pajak. 


\section{2) Fungsi Pajak}

Menurut Herry Purwono (2015:1) terdapat 2 fungsi pajak, yaitu:

a. Fungsi Penerimaan (Revenue)

Dikenal pula dengan istilah Fungsi Budgetair (Anggaran). Pajak yang berfungsi sebagai sumber dana yang diperuntukkan bagi pembiayaan pengeluaranpengeluaran pemerintah.

b. Fungsi Pemerataan (Redistribution)

Pajak yang dipungut oleh negara selanjutnya akan dikembalikan kepada masyarakat dalam bentuk penyediaan fasilitas publik diseluruh wilayah negara.

\section{3) Sistem Pemungutan Pajak}

Resmi (2019:29), dalam memungut pajak dikenal ada beberapa sistem, yaitu official assessment system, self assessment system, dan with holding system.

a. Official Assesment System adalah suatu sistem pemungutan pajak yang memberikan kewenangan aparatur perpajakan untuk menentukan sendiri jumlah pajak yang terutang setiap tahunnya sesuai dengan peraturan perundang-undangan perpajakan yang berlaku.

b. Self Assessment System yaitu suatu sistem pemungutan pajak yang memberikan wewenang wajib pajak dalam menentukan sendiri jumlah pajak terutang setiap tahunnya sesuai dengan peraturan perudang-undangan perpajakan yang berlaku.

With Holding System yaitu suatu sistem pemungutan pajak yang memberikan wewenang kepada pihak ketiga yang ditunjuk untuk menentukan besarnya pajak yang terutang oleh wajib pajak sesuai dengan peraturan perundang-undangan perpajakan yang berlaku.

\section{4) Pengelompok Pajak}

Ada tiga jenis pengelompokan pajak menurut Sukrisno (2014:7) antara lain:

a. Menurut sifatnya, pajak dikelompokkan menjadi dua yaitu:

$\checkmark$ Pajak Langsung adalah pajak yang pembebanannya tidak dapat dilimpahkan oleh pihak lain dan menjadi beban langsung Wajib Pajak (WP) yang bersangkutan. Contoh: Pajak Penghasilan.

$\checkmark$ Pajak Tidak Langsung adalah pajak yang pembebanannya dapat dilimpahkan kepada pihak lain. Contoh: Pajak Pertambahan Nilai (PPN) dan Pajak Penjualan atas Barang Mewah (PPnBM).

b. Menurut objeknya, pajak dikelompokan menjadi dua yaitu:

$\checkmark$ Pajak Subjektif adalah pajak yang berpangkal atau berdasarkan pada subjeknya yang dilakukan dengan mencari syarat objektifnya, dalam arti memperhatikan keadaan diri WP. Contoh: PPh.

$\checkmark$ Pajak Objektif adalah pajak pajak yang berpangkal atau berdasarkan pada objek tanpa memperhatikan keadaan diri WP. Contoh: PPN, PPnBM, PBB, dan Bea Materai (BM).

C. Menurut pemungutannya, pajak dikelompokkan menjadi dua yaitu:

$\checkmark$ Pajak Pusat adalah pajak yang dipungut oleh pemerintah dan digunakan untuk membiayai rumah tangga pemerintah pusat. Contoh: PPh, PPN, PPnBM, PBB, dan BM.

$\checkmark$ Pajak Daerah adalah pajak yang dipungut oleh pemerintah daerah dan 
digunakan untuk membiayai rumah tangga pemerintah daerah. Contoh: Pajak Reklame, Pajak Hiburan, Pajak Hotel dan Restoran, dan Pajak Kendaraan Bermotor.

\section{5) Agresivitas Pajak}

Menurut Martinez (2017:111) Agresivitas pajak adalah perilaku dalam kecenderungan melakukan manajemen laba, dimana agresivitas pajak biasa diukur menggunakan proksi dengan membandingkan jumlah laba dengan pajak.

Dalam penelitian ini penulis menggunakan rumus ETR dalam pengukuran agresivitas pajak. Alasan menggunakan rumus ETR karena rasio ini banyak digunakan oleh berbagai peneliti terdahulu dalam mengukur agresivitas pajak. ETR yang rendah menunjukan beban pajak penghasilan yang lebih kecil dari pada pendapatan sebelum pajak. Rumus untuk menghitung ETR adalah sebagai berikut:

$$
\mathrm{ETR}=\frac{\text { Beban Pajak Penghasilan }}{\text { Laba Sebelum Pajak }}
$$

\section{6) Likuiditas}

Menurut Kasmir (2015:130) rasio likuiditas adalahRasio likuiditas atau sering disebut dengan nama rasio modal kerja merupakan rasio yang digunakan untuk mengukur seberapa likuidnya suatu perusahaan. Caranya adalah dengan membandingkan komponen yang ada di neraca, yaitu total aktiva lancar dengan total passiva lancar (utang jangka pendek).

$$
\text { Current Ratio }=\frac{\text { Aset Lancar }}{\text { Kewajiban Lancar }}
$$

\section{7) Leverage}

Menurut Fahmi (2015:127) mendefinisikan bahwa leverage adalah Rasio yang mengukur seberapa besar perusahaan dibiayai dengan hutang. Penggunaan utang yang terlalu tinggi akan membahayakan perusahaan karena perusahaan akan masuk dalam kategori extreme leverage (utang ekstrim) yaitu perusahaan terjebak dalam tingkat utang yang tinggi dan sulit untuk melepaskan beban utang tersebut. Sehingga rumusnya sebagai berikut (Dewinta dan Setiawan 2016) leverage dapat dihitung dari:

$$
\text { Debt to Assets Ratio }=\frac{\text { Total Utang }}{\text { Total Aset }}
$$

\section{8) Profitabilitas}

Menurut Sartono (2015:122) profitabilitas adalah Kemampuan perusahaan memperoleh laba dalam hubunganya dengan penjualan, total aktiva maupun modal sendiri. Dengan demikian bagi investor jangka panjang akan sangat berkepentingan dengan analisis profitabilitas ini misalnya bagi pemegang saham akan melihat keuntungan yang benar-benar akan diterima dalam bentuk dividen.cara menghitung ROA yaitu:

$$
\text { Return On Assets }=\frac{\text { Laba Bersih }}{\text { Total Aset }}
$$




\section{METODE PENELITIAN}

Metode Penelitian ini menggunakan metode penelitian kuantitatif. Sugiyono (2014:402) penelitian kuantitatif yaitu penelitian dimana data yang disajikan dalam bentuk angka-angka. Data yang digunakan dalam penelitian ini adalah data sekunder dari perusahaan pertambangan yang terdaftar di Bursa Efek Indonesia periode 2014-2018 dan penelitian ini dilaksanakan di Bursa Efek Indonesia melalui website resmi BEl yaitu www.idx.co.id. Waktu penelitian dilakukan pada saat peneliti mengajukan riset untuk penelitian yaitu bulan Februari 2020.

\section{1) Populasi Penelitian}

Dalam penelitian ini yang menjadi populasi penelitian adalah perusahaan pertambangan yang terdaftar di Bursa Efek Indonesia tahun 2014-2018 yang berjumlah 47 perusahaan. Tetapi tidak semua populasi ini akan menjadi objek penelitian, sehingga perlu dilakukan pengambilan sampel lebih lanjut. Berikut namanama perusahaan yang dijadikan populasi dalam penelitian ini:

Tabel Perusahaan Yang Menjadi Populasi Penelitian

\begin{tabular}{|c|c|c|}
\hline No & $\begin{array}{c}\text { Kode } \\
\text { Perusahaan }\end{array}$ & Nama Perusahaan \\
\hline 1 & ADRO & Adaro Energy Tbk \\
\hline 2 & ARII & Atlas Resources Tbk \\
\hline 3 & ATPK & Bara Jaya Internasional Tbk \\
\hline 4 & BORN & Borneo Lumbung Energi \& Metal Tbk \\
\hline 5 & BOSS & PT Borneo Olah Sarana Sukses Tbk \\
\hline 6 & BSSR & Baramulti Suksessarana Tbk \\
\hline 7 & BUMI & Bumi Resources Tbk \\
\hline 8 & BYAN & Bayan Resources Tbk \\
\hline 9 & DEWA & Darma Henwa Tbk \\
\hline 10 & DOID & Delta Dunia Makmur Tbk \\
\hline 11 & DSSA & Dian Swastatika Sentosa Tbk \\
\hline 12 & FIRE & PT Alfa Energi Investama Tbk \\
\hline 13 & GEMS & Golden Energy Mines Tbk \\
\hline 14 & GTBO & Garda Tujuh Buana Tbk \\
\hline 15 & HRUM & Harum Energy Tbk \\
\hline 16 & INDY & Indika Energy Tbk \\
\hline 17 & ITMG & Indo Tambangraya Megah Tbk \\
\hline 18 & KKGI & Resource Alam Indonesia Tbk \\
\hline 19 & MBAP & PT Mitrabara Adiperdana Tbk \\
\hline 20 & $\mathrm{MYOH}$ & Samindo Resources Tbk \\
\hline 21 & PKPK & Perdana Karya Perkasa Tbk \\
\hline 22 & PTBA & Bukit Asam Tbk \\
\hline 23 & PTRO & Petrosea Tbk \\
\hline 24 & SMMT & Golden Eagle Energy Tbk \\
\hline 25 & TOBA & Toba Bara Sejahtra Tbk \\
\hline 26 & APEX & Apexindo Pratama Duta Tbk \\
\hline 27 & ARTI & Ratu Prabu Energi Tbk \\
\hline 28 & $\mathrm{BIPI}$ & PT Astrindo Nusantara Infrastruktur Tbk \\
\hline 29 & ELSA & Elnusa Tbk \\
\hline 30 & ENRG & Energi Mega Persada Tbk \\
\hline
\end{tabular}




\begin{tabular}{|l|l|l|}
\hline 31 & ESSA & Surya Esa Perkasa Tbk \\
\hline 32 & MEDC & PT Medco Energi Internasional Tbk \\
\hline 33 & MITI & Mitra Investindo Tbk \\
\hline 34 & RUIS & Radiant Utama Interinsco Tbk \\
\hline 35 & SURE & PT Super Energy Tbk \\
\hline 36 & ANTM & Aneka Tambang Tbk \\
\hline 37 & CITA & Cita Mineral Investindo Tbk \\
\hline 38 & CKRA & Cakra Mineral Tbk \\
\hline 39 & DKFT & Central Omega Resources Tbk \\
\hline 40 & INCO & Vale Indonesia Tbk \\
\hline 41 & MDKA & PT Merdeka Copper Gold Tbk \\
\hline 42 & PSAB & J Resources Asia Pasifik Tbk \\
\hline 43 & SMRU & SMR Utama Tbk \\
\hline 44 & TINS & PT Timah Tbk \\
\hline 45 & ZINC & PT Kapuas Prima Coal Tbk \\
\hline 46 & CTTH & Citatah Tbk \\
\hline 47 & SIAP & Sekawan Intipratama Tbk \\
\hline
\end{tabular}

Sumber: www.idx.co.id

\section{2) Sampel Penelitian}

Teknik sampling yang digunakan oleh penulis adalah teknik purposive sampling. Teknik purposive sampling yaitu teknik pengambilan sampel sumber data dengan pertimbangan tertentu, teknik ini menciptakan kriteria-kriteria tertentu yang digunakan sebagai teknik pengambilan, sehingga dapat memberikan data informasi yang sesuai kepada penulis untuk dijadikan bahan penelitian.

Adapun kriteria-kriteria perusahaan yang dijadikan sampel dalam penelitian ini adalah sebagai berikut:

a. Perusahaan pertambangan yang terdaftar di Bursa Efek Indonesia tahun 20142018.

b. Perusahaan pertambangan yang mempublikasikan laporan tahunan selama tahun penelitian.

c. Perusahaan pertambangan yang terdaftar tidak mengalami kerugian selama tahun penelitian.

d. Data outlier

Berikut ini adalah hasil pemilihan sampel yang telah memenuhi kriteria pada penelitian ini:

Tabel Sampel Penelitian

\begin{tabular}{|l|l|l|}
\hline No & Keterangan & Jumlah \\
\hline 1 & $\begin{array}{l}\text { Perusahaan pertambangan yang terdaftar di Bursa } \\
\text { Efek Indonesia tahun 2014-2018. }\end{array}$ & 47 \\
\hline 2 & $\begin{array}{l}\text { Perusahaan pertambangan yang tidak } \\
\text { mempublikasikan laporan tahunan selama tahun 2014- } \\
\text { 2018. }\end{array}$ & $(16)$ \\
\hline 3 & $\begin{array}{l}\text { Perusahaan pertambangan yang terdaftar tidak } \\
\text { mengalami kerugian selama tahun 2014-2018. }\end{array}$ & $(16)$ \\
\hline 4 & Data outlier & $(4)$ \\
\hline 5 & Jumlah sampel & 11 \\
\hline
\end{tabular}




\begin{tabular}{|l|l|l|}
\hline 6 & Jumlah observasi $(11 \times 5)$ & 55 \\
\hline
\end{tabular}

\section{Sumber: Data diolah, 2020}

Berikut ini nama-nama perusahaan pertambangan yang telah memenuhi kriteria dan terpilih menjadi sampel penelitian berdasarkan purposive sampling yang digunakan dapat dilihat pada tabel

Tabel Daftar Perusahaan yang Menjadi Sampel Penelitian

\begin{tabular}{|c|l|l|}
\hline No & \multicolumn{1}{|c|}{$\begin{array}{c}\text { Kode } \\
\text { Perusahaan }\end{array}$} & \multicolumn{1}{c|}{ Nama Perusahaan } \\
\hline 1 & ADRO & Adaro Energy Tbk \\
\hline 2 & ITMG & Indo Tambangraya Megah Tbk \\
\hline 3 & KKGI & Resource Alam Indonesia Tbk \\
\hline 4 & MBAP & PT Mitrabara Adiperdana Tbk \\
\hline 5 & MYOH & Samindo Resources Tbk \\
\hline 6 & TOBA & Toba Bara Sejahtera Tbk \\
\hline 7 & ELSA & Elnusa Tbk \\
\hline 8 & RUIS & Radiant Utama Interinsco Tbk \\
\hline 9 & PSAB & J Resources Asia Pasifik Tbk \\
\hline 10 & TINS & PT Timah Tbk \\
\hline 11 & CTTH & Citatah Tbk \\
\hline
\end{tabular}

Sumber: Data diolah, 2020

\section{HASIL DAN PEMBAHASAN}

\section{Uji Statistik Deskriptif}

Analisis statistik deskriptif akan memberikan gambaran atau deskripsi suatu data yang dilihat dari nilai minimum, maksimum, rata-rata (mean), dan standar deviasi yang dihasilkan dari variabel penelitian. Variabel-variabel dalam penelitian ini diuji secara statistik dengan menggunakan program SPSS seperti yang terlihat dalam tabel.

Tabel Statistik Deskriptif Descriptive Statistics

\begin{tabular}{|l|r|r|r|r|r|}
\hline & $\mathrm{N}$ & Minimum & Maximum & Mean & Std. Deviation \\
\hline Current Ratio & 55 &, 293 & 4,298 & 1,82462 &, 871415 \\
DAR & 55 &, 145 &, 781 &, 43273 &, 152789 \\
ROA & 55 &, 003 &, 365 &, 08736 &, 080913 \\
Agresivitas Pajak & 55 &, 207 &, 803 &, 35633 &, 112622 \\
Valid N (listwise) & 55 & & & & \\
\hline
\end{tabular}

Sumber: Data Olahan SPSS, 2020.

Berdasarkan tabel hasil statistik deskriptif diperoleh data sebanyak 55 data observasi yang berasal dari perkalian 5 tahun penelitian dari tahun 2014 sampai 2018 dengan jumlah sampel sebanyak 11 perusahaan. Tabel tersebut menggambarkan statistik deskriptif untuk variabel dependen agresivitas pajak (ETR) dengan variabel independen likuiditas (current ratio), leverage (DAR), dan profitabilitas (ROA). 
Hasil analisis statistik deskriptif terhadap variabel independen likuiditas yang diproksi dengan (current ratio) menunjukkan nilai minimum sebesar 0,293 diperoleh PT J Resources Asia Pasifik Tbk tahun 2015. Nilai maksimum sebesar 4,298 diperoleh PT Samindo Resources Tbk tahun 2016. Nilai mean atau nilai rata-rata current ratio 1,82462 atau $182,4 \%$. Sedangkan nilai standar deviasi sebesar 0,871415 menunjukan bahwa sampel memiliki sebaran likuiditas yang hampir sama antar asing-masing sampel.

Hasil analisis statistik deskriptif terhadap variabel independen leverage yang diproksi dengan (DAR) menunjukkan nilai minimum sebesar 0,145 diperoleh PT Resource Alam Indonesia Tbk tahun 2016. Nilai maksimum sebesar 0,781 diperoleh PT Citatah Tbk tahun 2014. Nilai mean atau nilai rata-rata DAR 0,43273 atau 43,2\%. Untuk nilai standar deviasi sebesar 0,152789 menunjukan bahwa leverage sampel memiliki sebaran yang hampir sama antar asing-masing sampel

Hasil analisis statistik deskriptif terhadap variabel independen profitabilitas yang diproksi dengan (ROA) menunjukkan nilai minimum sebesar 0,003 diperoleh PT Citatah Tbk Tbk tahun 2014 dan 2015. Nilai maksimum sebesar 0,365 diperoleh PT Mitrabara Adiperdana Tbk 2017. Nilai mean atau nilai rata-rata ROA0,08736 atau $8,7 \%$. Sedangkan nilai standar deviasi diperoleh sebesar 0,080913.

Hasil analisis statistik deskriptif terhadap variabel dependen agresivitas pajak yang diproksi dengan effective tax rate (ETR) menunjukkan nilai minimum sebesar 0,207 diperoleh PT Mitrabara Adiperdana Tbk tahun 2014. Nilai maksimum sebesar 0,803 diperoleh PT J Resources Asia Pasifik Tbk tahun 2015. Nilai mean atau nilai rata-rata ETR sebesar 0,35633 atau 35,6\%. Sedangkan nilai standar deviasi diperoleh sebesar 0,112622 yang menunjukan bahwa sampel memiliki sebaran effecitve tax rate yang hampir sama antar masing- masing sampel.

\section{Pengujian Uji Asumsi Klasik Uji Normalitas}

Pengujian ini bertujuan untuk melihat apakah data baik variabel independen maupun variabel dependen pada penelitian berdistribusi dengan normal. Uji normalitas yang digunakan dalam penelitian ini yaitu menggunakan analisis histogram, normal P-Plot, dan uji statistik melalui uji Kolmogorov-Smirnov. Hasil uji normalitas disajikan pada gambar berikut:

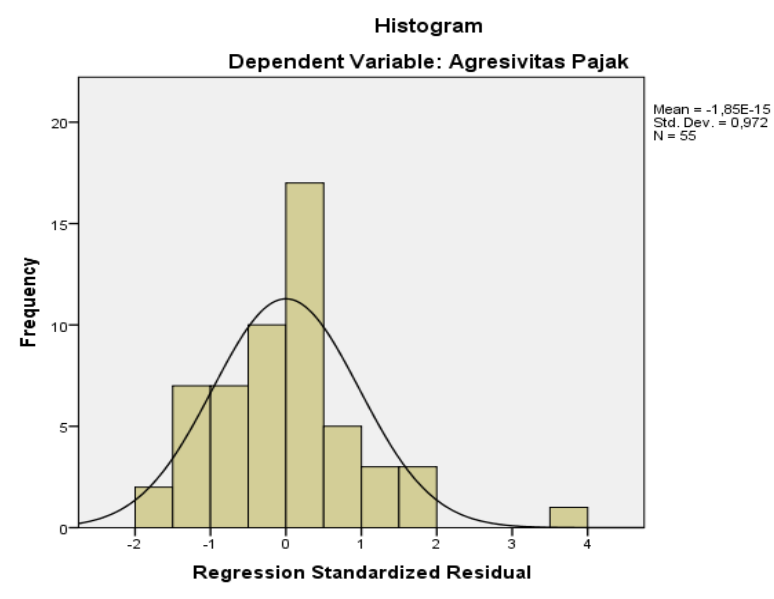

\section{Gambar Histogram Variabel Dependen Agresivitas Pajak Sumber: Data Olahan SPSS, 2020}


Berdasarkan gambar diatas menunjukan bahwa data yang digunakan dalam penelitian ini terdistribusi secara normal berbentuk simetris dan tidak menceng atau skewness ke kanan atau ke kiri sehingga dapat dikatakan bahwa model regresi memenuhi asumsi normalitas.

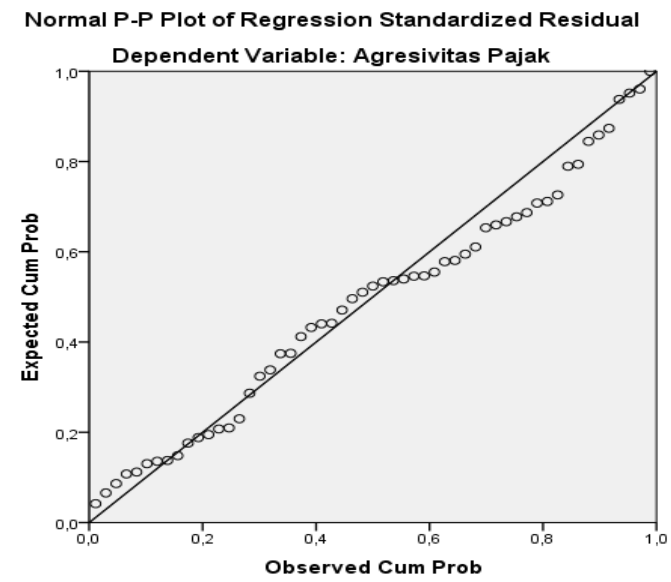

\section{Gambar Normal P-Plot of Regression Standarized Residual-Normal Sumber: Data Olahan SPSS, 2020}

Berdasarkan gambar diatas dapat dilihat bahwa titik-titik menyebar disekitar garis diagonal hal ini menunjukkan pola distribusi normal sehingga dapat disimpulkan bahwa model regresi memenuhi asumsi normalitas.

Tabel Uji Kolmogorov-Smirnov

\section{One-Sample Kolmogorov-Smirnov Test}

\begin{tabular}{|ll|r|}
\hline & & \multicolumn{2}{|c|}{ Unstandardized Residual } \\
\hline $\mathrm{N}$ & 55 \\
Normal & Mean &, 0000000 \\
Parameters & Std. &, 09410441 \\
Most Extreme & Absolute &, 105 \\
Differences & Positive &, 105 \\
& Negative &,- 049 \\
Test Statistic & &, 105 \\
Asymp. Sig. (2-tailed) &, $200^{c, d}$ \\
\hline
\end{tabular}
a. Test distribution is Normal.
b. Calculated from data.
c. Lilliefors Significance Correction.
d. This is a lower bound of the true significance.

Sumber: Data Olahan SPSS, 2020.

Berdasarkan hasil uji Kolmogorov-Smirnov pada tabel besarnya nilai Asymp.Sig (2-tailed)adalah sebesar $0,200>0,05$. Hal ini menunjukan bahwa data residual terdistribusi normal.

\section{Uji Multikolinearitas}

Uji multikolinearitas dilakukan dengan tujuan untuk menguji apakah dalam model regresi ditemukan adanya korelasi antar variabel bebas (independen). Hasil uji multikolinearitas adalah sebagai berikut: 
Tabel Uji Multikolinearitas Coefficients $^{a}$

\begin{tabular}{|c|c|c|c|c|c|c|c|}
\hline \multirow[b]{2}{*}{ Model } & \multicolumn{2}{|c|}{$\begin{array}{l}\text { Unstandardized } \\
\text { Coefficients }\end{array}$} & \multirow{2}{*}{$\begin{array}{c}\text { Standardized } \\
\text { Coefficients } \\
\text { Beta }\end{array}$} & \multirow[b]{2}{*}{$\mathrm{t}$} & \multirow[b]{2}{*}{ Sig. } & \multicolumn{2}{|c|}{$\begin{array}{l}\text { Collinearity } \\
\text { Statistics }\end{array}$} \\
\hline & B & $\begin{array}{l}\text { Std. } \\
\text { Error }\end{array}$ & & & & $\begin{array}{c}\text { Toleranc } \\
\mathrm{e}\end{array}$ & VIF \\
\hline (Constant) & ,448 & ,099 & & 4,544 & ,000 & & \\
\hline $\begin{array}{l}\text { Current } \\
\text { Ratio }\end{array}$ &,- 022 & 024 &,- 171 &,- 924 & 360 & ,402 & 2,490 \\
\hline DAR & ,003 & ,139 & ,005 & ,025 & ,980 & ,387 & 2,582 \\
\hline ROA &,- 610 & 197 &,- 438 & $-3,093$ & ,003 & ,682 & 1,466 \\
\hline
\end{tabular}

a. Dependent Variable: Agresivitas Pajak

Sumber: Data Olahan SPSS, 2020.

Dari tabel diatas, hasil perhitungan nilai tolerance menunjukkan tidak ada variabel independen yang memiliki nilai tolerance kurang dari 0,10 yaitu 0,402 untuk current ratio, 0,387 untuk DAR, dan 0,682 untuk ROA. Hasil perhitungan VIF juga menunjukan hal yang sama, yaitu tidak ada variabel independen yang memiliki nilai VIF lebih dari 10 yaitu 2,490 untuk current ratio, 2,582 untuk DAR, dan 1,466 untuk ROA. Hal ini menunjukkan bahwa tidak terjadi multikolinearitas antar variabel independen dalam penelitian ini.

\section{Uji Heteroskedastisitas}

Uji Heteroskedastisitas dilakukan dengan tujuan untuk menguji apakah dalam model regresi terjadi ketidaksamaan varian dari residual satu pengamatan ke pengamatan lain. Uji Heteroskedastisitas yang digunakan dalam penelitian ini menggunakan grafik scatterplot.

Scatterplot

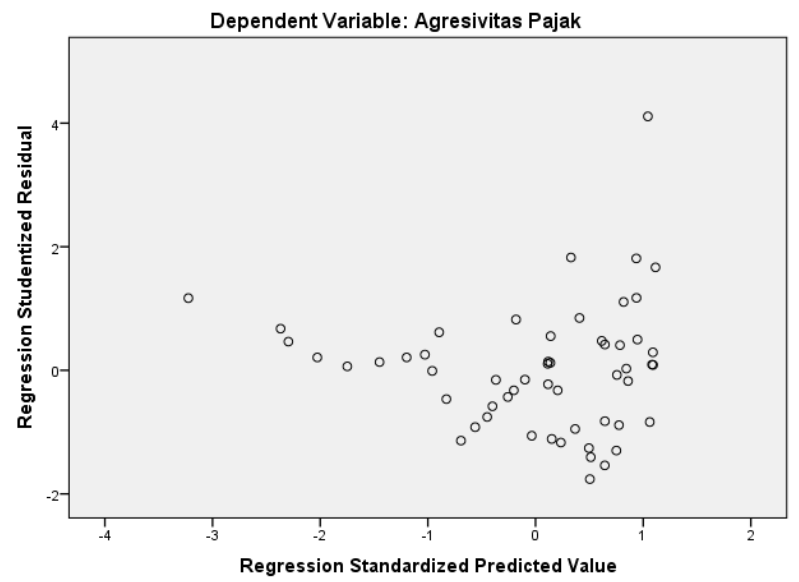

Gambar Uji Heteroskedastisitas

Sumber: Data Olahan SPSS, 2020.

Berdasarkan tampilan scatterplot pada gambar diatas dapat dilihat bahwa titik-titik menyebar secara acak dan tersebar baik diatas maupun dibawah angka 0 pada sumbu Y. Hal ini dapat disimpulkan bahwa tidak terjadi heteroskedastisitas pada model regresi. Sehingga model regresi layak dipakai untuk memprediksi hubungan antara profitabilitas, likuiditas, dan leverage dengan agresivitas pajak. 


\section{Uji Autokorelasi}

Uji autokorelasi bertujuan untuk menguji dalam model regresi linear ada atau tidak korelasi antara kesalahan pengganggu pada periode $t$ dengan kesalahan pengganggu pada periode t-1 atau periode sebelumnya. Uji autokorelasi pada penelitian ini menggunakan uji Durbin-Waston. Berikut ini hasil uji autokorelasi.

\section{Tabel Uji Autokorelasi \\ Model Summary}

\begin{tabular}{|l|c|r|r|r|r|}
\hline Model & $\mathrm{R}$ & $\mathrm{R}$ Square & $\begin{array}{c}\text { Adjusted R } \\
\text { Square }\end{array}$ & $\begin{array}{c}\text { Std. Error of } \\
\text { the Estimate }\end{array}$ & $\begin{array}{c}\text { Durbin- } \\
\text { Watson }\end{array}$ \\
\hline 1 &, $549^{\mathrm{a}}$ &, 302 &, 261 &, 096833 & 1,687 \\
\hline
\end{tabular}

a. Predictors: (Constant), ROA, Current Ratio, DAR

b. Dependent Variable: Agresivitas Pajak

Sumber: Data Olahan SPSS, 2020.

Berdasarkan tabel diatas nilai Durbin-Waston sebesar 1,687 pembanding menggunakan nilai signifikan $5 \%$, jumlah sampel 55 (n), dan jumlah variabel independen $3(\mathrm{k}=3)$, maka di tabel Durbin-Waston akan didapat nilai $\mathrm{dL}$ sebesar 1,452 dan du sebesar 1,681. Hasilnya adalah $\mathrm{du}<\mathrm{dw}<4$-(du) $(1,681<1,687<$ $2,319)$, maka dapat disimpulkan tidak terdapat autokorelasi antar residual.

\section{Analisis Regresi Berganda}

Analisis regresi berganda bertujuan untuk melihat bagaimana respon dari variabel dependen apabila variabel dependennya berubah (naik atau turun). Berikut merupakan hasil analisis regresi berganda menggunakan spss.

Tabel Uji Analisis Regresi Berganda Coefficients $^{\mathrm{a}}$

\begin{tabular}{|c|c|c|c|c|c|c|c|}
\hline \multirow[b]{2}{*}{ Model } & \multicolumn{2}{|c|}{$\begin{array}{l}\text { Unstandardized } \\
\text { Coefficients }\end{array}$} & \multirow{2}{*}{$\begin{array}{c}\text { Standardized } \\
\text { Coefficients } \\
\text { Beta }\end{array}$} & \multirow[b]{2}{*}{$t$} & \multirow[b]{2}{*}{ Sig. } & \multicolumn{2}{|c|}{$\begin{array}{l}\text { Collinearity } \\
\text { Statistics }\end{array}$} \\
\hline & $B$ & Std. Error & & & & Tolerance & VIF \\
\hline (Constant) & , 448 & ,099 & & 4,544 & ,000 & & \\
\hline $\begin{array}{l}\text { Current } \\
\text { Ratio }\end{array}$ &,- 022 & 024 &,- 171 &,- 924 & 360 & 402 & 2,490 \\
\hline DAR & ,003 & , 139 & ,005 & ,025 & ,980 & 387 & 2,582 \\
\hline $\mathrm{ROA}$ &,- 610 & 197 &,- 438 & $-3,093$ & ,003 & 682 & 1,466 \\
\hline
\end{tabular}

a. Dependent Variable: Agresivitas Pajak

\section{Sumber: Data Olahan SPSS, 2020.}

Berdasarkan tabel diatas maka dapat dibuat persamaan regresi berganda sebagai berikut:

Agresivitas Pajak $=0,448-(-0,022) X_{1}-0,003 X_{2}-(-0,610) X_{3}+e$

Dimana:

$$
\begin{array}{ll}
\mathrm{Y} & =\text { Agresivitas Pajak } \\
\mathrm{X}_{1} & =\text { Liabilitas } \\
\mathrm{X}_{2} & =\text { Leverage } \\
\mathrm{X} 3 & =\text { Profitabilitas } \\
e & =\text { Eror }
\end{array}
$$


Adapun interpretasi dari persamaan tersebut adalah sebagai berikut:

Konstanta menunjukan angka 0,448, hal ini berarti apabila nilai variabel independen likuiditas, leverage, dan profitabilitas bernilai 0 , maka variabel dependen yaitu agresivitas pajak yang diproksi dengan Effective Tax Rate (ETR) akan memiliki nilai sebesar 0,448 atau $44,8 \%$.

Koefisien regresi variabel likuiditas sebesar $-0,022$, hal ini berarti apabila nilai variabel likuiditas mengalami kenaikan sebesar 1 satuan dan variabel lain nilainya konstan, maka variabel dependen yaitu agresivitas pajak yang diproksi dengan Effective Tax Rate (ETR) akan mengalami penurunan sebesar 0,022 atau 2,2\%.

Koefisien regresi variabel leverage sebesar 0,003 , hal ini berarti apabila nilai variabel likuiditas mengalami kenaikan sebesar 1 satuan dan variabel lain nilainya konstan, maka variabel dependen yaitu agresivitas pajak yang diproksi dengan Effective Tax Rate (ETR) akan mengalami kenaikan sebesar 0,003 atau 0,3\%.

Koefisien regresi variabel profitabilitas sebesar $-0,610$, hal ini berarti apabila nilai variabel likuiditas mengalami kenaikan sebesar 1 satuan dan variabel lain nilainya konstan, maka variabel dependen yaitu agresivitas pajak yang diproksi dengan Effective Tax Rate (ETR) akan mengalami penurunan sebesar 0,610 atau $61 \%$.

\section{Uji Hipotesis \\ Koefisien Determinasi $\left(\mathbf{R}^{2}\right)$}

Koefisien determinasi menunjukan seberapa besar hubungan antara variabel independen secara simultan terhadap variabel dependen. Nilai koefisien determinasi $(\mathrm{R})$ berkisar 0 hingga 1 . Jika nilai $R$ semakin mendekati 1 maka hubungan yang terjadi semakin kuat. Namun apabila nilai $R$ semakin medekati 0 maka hubungan yang terjadi akan semakin lemah. Berikut merupakan hasil uji koefisien determinasi dalam penelitian ini.

Tabel Uji Koefisien Determinasi Model Summary

\begin{tabular}{|l|r|r|r|r|}
\hline Model & $\mathrm{R}$ & $\mathrm{R}$ Square & $\begin{array}{c}\text { Adjusted } \mathrm{R} \\
\text { Square }\end{array}$ & $\begin{array}{c}\text { Std. Error of the } \\
\text { Estimate }\end{array}$ \\
\hline 1 &, $549^{\mathrm{a}}$ &, 302 &, 261 &, 096833 \\
\hline
\end{tabular}

a. Predictors: (Constant), ROA, Current Ratio, DAR

Sumber: Data Olahan SPSS, 2020.

Dari tabel diatas hal-hal yang dapat di interpretasikan adalah sebagai berikut:

1. Nilai $R$ sebesar 0,549 menunjukkan hubungan antara variabel independen yaitu likuiditas, leverage, dan profitabilitas dengan variabel dependen yaitu sebesar $54,9 \%$.

2. Nilai $R$ Square 0,302 atau sebesar $30,2 \%$ yang berarti bahwa agresivitas pajak mampu di prediksi oleh likuiditas, leverage, dan profitabilitas sebesar 30,2\%. Sisanya yaitu sebesar $69,8 \%$ mampu diprediksi oleh variabel lain yang tidak diteliti dalam penelitian ini.

3. Nilai Adjusted $R$ Square 0,261 atau sebesar $26,1 \%$ yang berarti bahwa agresivitas pajak mampu di prediksi oleh likuiditas, leverage, dan profitabilitas sebesar $26,1 \%$. Sisanya yaitu sebesar $73,9 \%$ mampu diprediksi oleh variabel lain yang tidak diteliti dalam penelitian ini. 
4. Terdapat dua pilihan dalam menentukan koefisien determinasi yaitu, $R$ Square atau Adjusted $R$ Square. Dalam penelitian ini digunakan Adjusted $R$ Square karena jumlah variabel lebih dari dua variabel. Sehingga nilai koefisien determinasi adalah sebesar 26,1\%.

5. Nilai standart error of the estimate yang diperoleh adalah 0,096833 semakin kecil nilai yang diperoleh, maka model regresi yang dihasilkan akan semakin tepat untuk memprediksi variabel.

\section{Uji Signifikansi Individuasi (Uji Statistik t)}

Uji ini bertujuan untuk melihat apakah setiap variabel independen secara parsial memiliki pengaruh yang signifikan terhadap variabel dependen. Dengan ketentuan jika nilai signifikan $>0,05$ maka secara parsial tidak ada pengaruh signifikan terhadap variabel dependen. Namun, terjadi sebaliknya, jika nilai signifikan $<0,05$ maka terdapat pengaruh signifikan secara parsial antara variabel independen dengan variabel dependen.

Langkah lain juga dapat diambil adalah dengan membandingkan nilai thitung dengan $t_{\text {tabel. }}$ Jika nilai thitung $>t_{\text {tabel }}$ maka terdapat pengaruhsignifikan secara parsial variabel independen terhadap variabel dependen. Sebaliknya Jika nilai $t_{\text {hitung }}<t_{\text {tabel }}$ maka tidak terdapat pengaruhsignifikan secara parsial variabel independen terhadap variabel dependen. Berikut merupakan hasil uji t dari penelitian.

Tabel Uji Signifikansi Individuasi (Uji t)

Coefficients $^{a}$

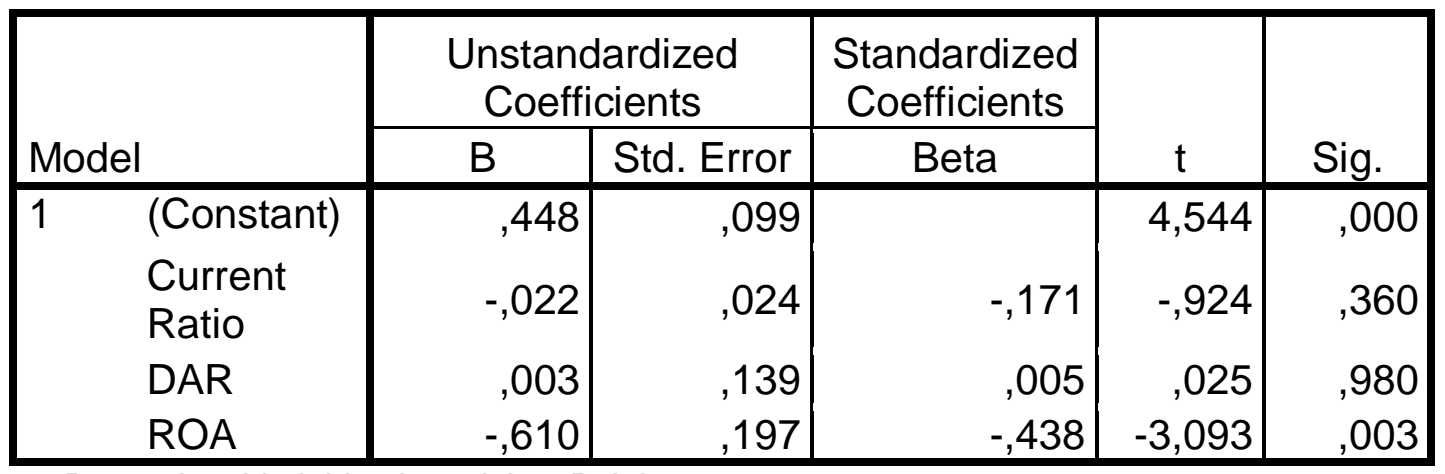

a. Dependent Variable: Agresivitas Pajak

Sumber: Data Olahan SPSS, 2020.

Berdasarkan tabel diatas dapat dilihat bahwa variabel likuiditas (current ratio) memilik nilai sig 0,360 $>0,05$ dan nilai thitung sebesar 0,924 dengan tabel 2,007 berarti $0,924<2,007$, maka dapat disimpulkan bahwa H1 ditolak yang berarti likuiditas tidak berpengaruh terhadap agresivitas pajak.

Variabel leverage (DAR) memiliki nilai sig $0,980>0,005$ dan nilai thitung sebesar 0,025 dengan tabel 2,007 berarti 0,025 2,007 maka dapat disimpulkan bahwa $\mathrm{H} 2$ ditolak yang berarti leverage tidak berpengaruh terhadap agresivitas pajak

Variabel profitabilitas $(\mathrm{ROA})$ memiliki nilai sig $0,003<0,005$ dan nilai thitung sebesar 3,093 dengan $t_{\text {tabel }}$ 2,007 berarti 3,093 > 2,007 maka dapat disimpulkan bahwa H3 diterima yang berarti profitabilitas berpengaruh signifikan terhadap agresivitas pajak. 


\section{Uji Signifikansi Simultan (Uji Statistik F)}

Uji $F$ atau uji signifikansi simultan adalah uji untuk mengetahui apakah variabel independen secara bersama-sama atau simultan mempengaruhi variabel dependen. Variabel independen akan berpengaruh secara simultan terhadap variabel dependen apabila nilai $F<0,05$. Sebaliknya, apabila nilai $F>0,05$ maka tidak ada pengaruh secara simultan variabel independen terhadap variabel dependen. Pengambilan keputusan juga dapat dilakukan dengan membandingkan antara nilai $F_{\text {hitung }}$ dengan $F_{\text {tabel. }}$ Variabel independen akan berpengaruh secara simultan terhadap variabel dependen apabila nilai $F_{\text {hitung }}>F_{\text {tabel }}$. Sebaliknya apabila $F_{\text {hitung }}<F_{\text {tabel }}$ maka variabel independen tidak berpengaruh secara simultan terhadap variabel dependen. Berikut hasil uji Signifikansi Simultan pada penelitian.

Tabel Uji Signifikansi Individuasi (Uji F) ANOVA $^{\mathrm{a}}$

\begin{tabular}{|c|c|c|c|c|c|c|}
\hline & & $\begin{array}{l}\text { Sum of } \\
\text { Squares }\end{array}$ & $\mathrm{df}$ & $\begin{array}{c}\text { Mean } \\
\text { Square }\end{array}$ & $F$ & Sig. \\
\hline \multirow[t]{3}{*}{1} & Regression & ,207 & 3 & \multirow{3}{*}{$\begin{array}{l}\text {,069 } \\
009\end{array}$} & \multirow[t]{3}{*}{7,349} & \multirow[t]{3}{*}{, $000^{b}$} \\
\hline & Residual & ,478 & 51 & & & \\
\hline & Total & 685, & 54 & & & \\
\hline
\end{tabular}

a. Dependent Variable: Agresivitas Pajak

b. Predictors: (Constant), ROA, Current Ratio, DAR

Sumber: Data Olahan SPSS, 2020.

Dari Tabel diatas dapat disimpulkan bahwa variabel independen secara simultan berpengaruh. Hal ini dapat dibuktikan dari nilai signifikansi $0,000<0,005$ dan nilai $F_{\text {hitung }}$ sebesar 7,394 dan $F_{\text {tabel }}$ sebesar 2,79 berarti 7,394 >2,79 maka dapat disimpulkan $\mathrm{H} 4$ diterima yang berarti likuiditas, leverage, dan profitabilitas secara simultan berpengaruh terhadap agresivitas pajak.

\section{E. KESIMPULAN DAN SARAN}

\section{1) Kesimpulan}

Penelitian ini bertujuan untuk mengetahui pengaruh likuiditas, leverage, dan profitabilitas terhadap agresivitas pajak yang diukur menggunakan ETR. Data dalam penelitian ini berjumlah 55 yang diambil dari perusahaan pertambangan yang terdaftar di BEl tahun 2014-2018 yang telah memenuhi kriteria penelitian. Berdasarkan data yang dikumpulkan dan hasil pengujian yang telah dilakukan terhadap permasalahan dengan menggunakan model regresi berganda maka dapat disimpulkan sebagai berikut:

a. Secara parsial, likuiditas tidak berpengaruh terhadap agresivitas pajak.

b. Secara parsial, leverage tidak berpengaruh terhadap agresivitas pajak.

c. Secara parsial, profitabilitas berpengaruh signifikan terhadap agresivitas pajak.

d. Nilai Adjusted $R$ Square 0,261 atau sebesar 26,1\% yang berarti bahwa agresivitas pajak mampu di prediksi oleh likuiditas, leverage, dan profitabilitas sebesar $26,1 \%$. Sisanya yaitu sebesar $73,9 \%$ mampu diprediksi oleh variabel lain yang tidak diteliti dalam penelitian ini.

e. Nilai standart error of the estimate yang diperoleh adalah 0,096833 semakin kecil nilai yang diperoleh, maka model regresi yang dihasilkan akan semakin tepat untuk memprediksi variabel. 


\section{2) Saran}

Saran yang dapat diberikan dari penelitian ini adalah sebagai berikut:

a. Penelitian selanjutnya diharapkan dapat menambahkan variabel lain yang erat kaitannya dengan agresivitas pajak yang tidak diteliti dalam penelitian ini seperti nilai perusahaan, kepemilikan institusional, corporate social responsibility, intensitas modal,komisaris independen, ataupun ukuran perusahaan, dimana variabel tersebut berpengaruh terhadap agresivitas pajak.

b. Untuk Peneliti selanjutnya disarankan dapat memperluas ruang lingkup penelitiannya, tidak hanya pada perusahaan pertambangan namun juga pada perusahaan di sektor-sektor lainnya seperti perusahaan jasa, sektor keuangan atau perbankan, dan lainnya.

c. Peneliti selanjutnya dapat menggunakan proksi agresivitas pajak selain ETR misalnya Cash Effective Taxe Rate (CETR), Net Profit Margin (NPM), dan Book Tax Differences (BTD).

d. Perusahaan sebaiknya lebih mempertimbangkan keputusan mengenai perpajakannya agar tidak melakukan tindakan agresivitas pajak. Karena hal tersebut dapat merugikan perusahaan seperti perusahaan akan dikenakan denda, turunnya harga saham, dan lain-lain

\section{DAFTAR PUSTAKA}

Agoes, Sukrisno. 2014. Akuntansi Perpajakan, Edisi 3. Jakarta: Salemba Empat.

Fahmi, Irham. 2015. Pengantar Manajemen Keuangan Teori dan Soal Jawab. Bandung: Alfabeta.

Kasmir. 2013. Analisis Laporan Keuangan. Edisi 1. Cetakan ke-6. Jakarta: Rajawali Pers.

Purwono Herry.2015.Dasar-Dasar Perpajakan dan Akuntansi Pajak.Jakarta: Erlangga

Resmi, Siti. 2019. Perpajakan Teori dan Kasus. Edisi 11 Buku 1. Jakarta: Penerbit Salemba Empat.

Sartono, Agus. 2015. Manajemen Keuangan Teori dan aplikasi. Edisi 4. Yogyakarta: BPFE.

Sugiyono. 2017. Metode Penelitian Kuantitatif, Kualitatif, dan Kombinasi.Bandung: Alfabeta. 